\title{
"Disastrous Adoption"? Representations of Fetal Alcohol Syndrome and Disability in Recent Native North American Writing
}

\section{Shackleton, Mark Hugh James}

Palgrave Macmillan

2017

Shackleton, M H J 2017 , "Disastrous Adoption"? Representations of Fetal Alcohol Syndrome and Disability in Recent Native North American Writing . in S Mark (ed.), International Adoption in North American Literature and Culture : Transnational, Transracial and Transcultural Narratives . Palgrave Macmillan , Basingstoke , pp. 51-68 . https://doi.org/10.1007/978-3-319-599

http://hdl.handle.net/10138/310284

https://doi.org/10.1007/978-3-319-59942-7_3

unspecified

acceptedVersion

Downloaded from Helda, University of Helsinki institutional repository.

This is an electronic reprint of the original article.

This reprint may differ from the original in pagination and typographic detail.

Please cite the original version. 


\title{
“Disastrous Adoption”? Representations of Fetal Alcohol Syndrome and Disability in Recent Native North American Writing
}

\author{
Mark Shackleton $1 \square$ \\ Email Mark.Shackleton@helsinki.fi
}

\section{Mark Shackleton}

is Senior Lecturer and Adjunct Professor at the Department of Modern Languages (English), University of Helsinki, He has published widely on Native North American writing and postcolonial studies, including articles on Tomson Highway, Thomas King, Monique Mojica, Gerald Vizenor, Louise Erdrich, and Simon J. Ortiz. Recent publications include the chapter on Canada in The Routledge Companion to Postcolonial Studies (2007); Diasporic Literature and Theory: Where Now? (ed. Mark Shackleton, 2008); Canada: Images of a Post/National Society (ed. Gunilla Florby, Mark Shackleton and Katri Suhonen, 2009); and he is a contributor to the volume Thomas King: Works and Impact (ed. Eva Gruber, 2012).

1 Department of Modern Languages, University of Helsinki, Helsinki, Finland

\section{Abstract}

The abstract is published online only. If you did not include a short abstract for the online version when you submitted the manuscript, the first paragraph or the first 10 lines of the chapter will be displayed here. If possible, please provide us with an informative abstract.

Chapter 3 focuses on the adoption of children with a severe handicap, specifically Native North American children with fetal alcohol syndrome (FAS). The primary text examined is Michael Dorris's The Broken Cord (1989), the autobiographical account of the adoption by a single father of a young Sioux child with FAS. Dorris's account can be read in terms of what Marianne Novy has called the archetype of "the disastrous adoption," an Oedipus-like tale of "disastrous" revelation. Critics of Dorris's 1989 work point to the way he has framed his account within tropes of disaster, emphasizing the despair of the disillusioned adoptive father, and de-emphasizing the individuality and worth of his adopted son. Dorris's work, moreover, can be seen as an instance of "out-of-tribe adoption" in that Dorris was not Sioux (he was, in fact, part Modoc). Since the passage of the Indian Child Welfare Act in 1978, there has been official recognition in US law that out-of-tribe adoption of Native adoptees by white families has threatened the integrity of tribal life, and that steps should be taken to support within-tribe adoption. Two texts by Native North American writers, Tomson Highway's play Dry Lips Oughta Move to Kapuskasing (1989) and Louise Erdrich's novel Four Souls (2004) are then explored for their representation of Native children with FAS. In these texts the notion of out-of-tribe adoption is implicitly challenged and the benefits of within-tribe succoring are foregrounded.

Since the passage of the Indian Child Welfare Act in 1978 there has been official recognition in US law that out-of-tribe adoption of Native adoptees by white families has threatened the integrity of tribal life, and that counter steps should be taken, wherever possible, to seek within-tribe adoption. The case of children with fetal alcohol syndrome (FAS), however, raises the question whether there are sufficient resources and funds available to provide adequate support for adoptive children with quite severe special needs. The issue of Native children with FAS came to general attention in the USA with the publication of Michael Dorris's The Broken Cord (1989), the autobiographical account of the adoption by a single father 
of a young Sioux child with FAS. Dorris's account could be read in terms of what Marianne Novy has called the archetype of "the disastrous adoption,", which, like the story of Oedipus, begins with confidence but then through a series of disclosures becomes a tragic tale of disastrous revelation. Following the initial popular success of The Broken Cord, responses by both Native cultural nationalists like Elizabeth Cook-Lynn, and from the field of ethics and disability studies, as in the work of G. Thomas Couser, have questioned what they see as representational biases in this autobiographical work. Briefly stated, critics of Dorris's The Broken Cord point to the way he has framed his account within tropes of disaster, emphasizing the despair of the disillusioned adoptive father who finds that his son cannot overcome his inherited defects, and de-emphasizing the individuality and worth of his adopted son, notwithstanding his disability. This leads me to discuss representations of disability in two Native North American writers: the intellectually disabled Zhaboonigan Peterson in Tomson Highway's The Rez Sisters (1988), and two individuals with FAS—Dickie Bird Halked in Highway's Dry Lips Oughta Move to Kapuskasing (1989) and John James Mauser II in Louise Erdrich's Four Souls (2004). What is clear in these works is that the disabled or FAS individual is not rejected or adopted out of the tribe. In The Rez Sisters the orphaned Zhaboonigan is adopted within the extended family network of the rez. In Dry Lips, Dickie Bird commits horrendous acts, but is not rejected by the tribal community. In Four Souls, John James is not abandoned by his birth mother, and in fact he provides crucial support at a moment of crisis in the novel. I would argue that these texts emphasize the spirit of the 1978 Indian Child Welfare Act: implicitly, the notion of out-of-tribe adoption is challenged and the benefits of within-tribe succoring are foregrounded.

AQ1

\section{Native North American Transracial Adoption: The Historical Background}

It would be a distortion to talk about transracial adoption in Native North America today without considering it within the context of history. In Canada, the Indian Act (1876), for example, defined status Indians as wards of the state. This, in effect, meant that the entire Aboriginal community were legal adoptees, and it was under the paternalistic care of the state that Aboriginal children were adopted out to white foster homes. In 1997, a well-known study of Canadian First Nations children by Fournier and Crey estimated that, by the end of the 1960s, 30-40\% of all legal wards were Aboriginal children (Natives, however, representing only $4 \%$ of the national population). ${ }^{2}$ By the late 1970 s, one in four Indian children in Canada were separated from their parents for all or part of their childhood; this figure was estimated as one in three if non-status and Métis children were included. ${ }^{3}$ In the United States some sources estimate that during the 1960s as many as $25-35 \%$ of Indian children were removed from their Indigenous communities and placed in non-Indian homes. ${ }^{4}$ These figures sum up what has been called the "scoop up" of the 1960s. It parallels similar forced assimilation policies for Aboriginals in Australia, whose adopted children became known as the "stolen generation." The effect of these forced assimilation policies on Native children's sense of identity, not to mention the pain caused to Native parents, is obvious. Not mincing its words, on June 2, 2015, Canada's Truth and Reconciliation Commission labeled its country's former policies toward Native families and children "cultural genocide.",

It is against this historical backcloth that we should not be surprised to see resistance to the notion of transracial and transcultural adoption among Native North American communities. The "scoop up" experience is reflected by key semi-autobiographical texts in First Nations writing, such as Beatrice Mosionier's In Search of April Raintree (1983) or Tomson Highway's Kiss of the Fur Queen (1998). Time and again, the return to psychic health for the estranged Native protagonist is associated with "homecoming," the return to tribal customs and conventions that have been lost through assimilative policies. The "homecoming" theme is a thread that links the work of virtually all the major Native North American writers, including N. Scott Momaday, Leslie Marmon Silko, Louise Erdrich, and others. ${ }^{6}$ 
Moreover, not infrequently, images of violence and rape are used to represent the pressures of a dominant and racist culture, and the psychological effects of cultural assimilation are foregrounded. In Sherman Alexie's Indian Killer (1998), for example, the in-between Native protagonist, John Smith, adopted by a white family, is represented as suffering from extreme schizophrenia. ${ }^{7}$

For historical reasons, the notion of forced cultural assimilation, transcultural adoption or fostering in Native North American writing is more likely to evoke negative than positive images. Tomson Highway's bestselling novel, Kiss of the Fur Queen, for example, provides a representation of the sexual abuse of Native children in residential schools, and in Gerald Vizenor's Father Meme (2008) an Anishinaabe altar boy reveals the abuses of a "sleazy priest" at the Indian Mission church. In both cases, the abusive priest is represented as a windigo, the terrible child-eating cannibal of Anishinaabe legends. As Siobhan Senier has pointed out, "The Weetigo [windigo] is [...] often invoked today by indigenous people as a metaphor for colonialism-violent and voracious." ${ }^{8}$ The residential school system for Native children, which reached its height in the 1960s in Canada and the USA, can certainly be seen as a form of cultural adoption, in which the assumed authority of the dominant cultural group and the assumed inferiority of the assimilated Native could allow abuses to thrive unchecked. In the late 90s, Sherman Alexie, a writer very much in touch with contemporary issues of urbanized and reservation Native Americans, published Indian Killer, ultimately a critical representation of transracial adoption. The white adoptees in this novel, albeit naïve, are sympathetically drawn, but the main emphasis is on the adoptee misfit, whose cultural deracination is shown to have devastating psychological effects. Adoption has been represented in many ways, and recently John McLeod has posited a constructive rethinking of adoption in literature, moving from the passivity and determinism of the notion of "being adopted" to the active world creation of "adoptive being." "That said, it would be a hard task to find a single example of a Native North American writer who represents adoption of a Native American child by a white family in positive terms. ${ }^{10}$

Outside the world of literature, changing attitudes to the extra-tribal adoption of Native children between the 1950s and late 1970s can be shown by the passing of the Indian Child Welfare Act (ICWA) in 1978. The ICWA represented a reaction against de-tribalization, so that adoption of Native children living on reservations now came within the jurisdiction of tribal courts, with the added understanding that such children should remain within their own families wherever possible.

\section{Michael Dorris's the Broken Cord: Fetal Alcohol Syndrome and the "Disastrous Adoption"}

With this historical background in mind, we can now turn to literary representations of adoption in Native North American writing. According to Marianne Novy, in Western literature, three primary mythic stories have traditionally been used to imagine adoption: the happy adoption (the Oliver Twist story), the happy discovery (The Winter's Tale story), and the disastrous adoption and discovery (the Oedipus story). ${ }^{1}$ Michael Dorris's autobiographical The Broken Cord, about his adoption of a Native child with fetal alcohol syndrome, can be seen as a narrative of "disastrous adoption."

Much of The Broken Cord can be read as an "educational text" which provides strong warnings about prenatal drinking. Talking with his son, Dorris bluntly puts it this way: "If I write the book this way [...] maybe what happened to you won't happen to somebody else." 12 Or, as Couser puts it, The Broken Cord might be read as a memoir which provides "valuable resources for other parents faced with situations that may be especially demanding." 13 Much of the book is given over to detailing the physical, mental, and behavioral problems of the FAS child, including abnormal appearance, low intelligence, and an inability to comprehend social norms. His own son's "lack of a particular kind of imagination," 14 an inability to foresee possible consequences, ${ }^{15}$ is stressed. Dorris points out that FAS and the supposedly milder condition of FAE (fetal alcohol effects) are global problems, but in North America there would appear to 
be a particularly high incidence of both in Native American communities. Many facts and figures are supplied to support this claim.

Strangely, FAS and FAE have only relatively recently come to world attention, and, in the States at least, Michael Dorris's autobiographical The Broken Cord did much to draw attention to FAS as a condition and to create an awareness of what it might be like for a parent to adopt a child with FAS. The Broken Cord was published in 1989, became a New York Times bestseller, and was made into a TV movie in 1992. Michael Dorris, part Modoc on his father's side, was twenty-six when, as a single father, he adopted a three-year-old Lakota Sioux child, who he was told was intellectually disabled. In literary terms, The Broken Cord can be conceived of as a discovery narrative; it charts the stages by which the adoptive father comes to realize how little he can do to develop his child's intellectual capabilities. Dorris comes eventually to accept the opinion of experts that "they [FAS victims] don't learn from experience." ${ }^{16}$ The title evokes the umbilical cord, the link that introduces poison into the fetus. The cord is severed at birth, but with the FAS child the effects last a lifetime: "My son will forever travel through a moonless night with only the roar of wind for company," ${ }^{17}$ writes Dorris. Here, in the markedly literary imagery of darkness and threat, Dorris is clearly speaking for and interpreting the "other," transposing his own disenchantment onto the unknown territory of his son's thoughts and feelings. The primary arc of the narrative is Dorris's discovery of his own impotence in the face of biological determinism. Adopting as a single parent with an enormous belief in the positive power of upbringing, Dorris's "broken cord" is a "broken contract," the grim acknowledgement of disillusionment and failure, and, thus, on his son's birthdays, Dorris grieves for what his son "should have been." ${ }^{18}$ His initial belief in the power of nurture gives way to a shocked acceptance of the power of nature, a realization that hits him "like a Mack truck," as study after study on FAS weights "'nature' as more important than "nurture.",19 The movement of the narrative from optimism to pessimism, from lightness to dark, clearly places The Broken Cord within the "disastrous adoption" paradigm.

It is worthwhile at this point to consider some of the criticisms that Dorris's book has received. Firstly, the rhetoric of the book is curiously close to the archetype or stereotype of the Indian as the "dying race." Dorris's realization that his son is "a microcosm of a much larger picture" 20 lends the biography an apocalyptic tone. As Cook-Lynn points out, the "broken cord" of the title thus evokes the "broken hoop" of Black Elk Speaks, a symbol which signals the end of Sioux nationhood. ${ }^{21}$ Margit Stange has also critiqued Dorris's rhetoric of "epidemic" and "race suicide",22 in The Broken Cord. Dorris's argument, put bluntly, is that if more and more children have FAS, tribal life as we know it will die out. In his final paragraph, Dorris writes: "He [his son] doesn't wonder where he came from, where he's going. He doesn't ask who he is, or why." 23 The implication is that the damaged individual, a microcosm of a "larger picture," the tribe at large, exists with no sense of the future or of identity. His son is presented as drowning, or experiencing a kind of living death: "my son, conceived and grown in an ethanol bath, lives each day in the act of drowning. For him there is no shore." 24

Secondly, the main emphasis on "the cure" focuses on Indian women. Both Dorris in The Broken Cord and, in the Foreword to the book, Louise Erdrich, his wife and literary collaborator at that time, state that if alcoholic mothers do not stop drinking, then they should be jailed during pregnancy to prevent damage to the fetus. This, of course, is a short-term measure, but if this is the main emphasis, then the wider picture of historical and political contexts and causes is placed in the background. As Gerald Vizenor has put it, "Indeed, alcohol is a poison, but must tribal women bear once more the moral burdens of manifest manners?" 25 The stress laid on the sins of the "irresponsible" birth mother is, of course, a familiar feature of adoption procedures even in relatively recent times. ${ }^{26}$

Thirdly, Dorris's "Indian autobiography"27 is an asymmetrical collaboration in which Dorris as a mixed-blood anthropologist speaks for and interprets the thoughts and feelings of his "informant," his 
son. Or rather, Dorris interprets what he sees as a lack of thoughts and feelings:

Don't talk to him of mountains, of tropical beaches. Don't ask him to swoon at sunrises or marvel at the filter of light through leaves. He's never had time for such things, and he does not believe in them. ${ }^{28}$

In fact, Dorris's son, called Adam in the biography (his real name is Abel), is given a postscript in which he tells his own life story in just over twelve pages. Adam might not rhapsodize about tropical beaches and light through the trees, but his self-portrait reveals him both as a character and a speaker/writer (the spelling and punctuation are his).

Then after that happened I did a very stupid thing while my father and louise was out to dinner that very night . I went into my sister,s bedroom and fell asleep on her bed until my father and mother came home that very night. When they came up stairs to go to bed that night they found me lyeing on madeline,s bed. And I got cought right there. My father asked me over and over and over what I was doing madeline,s room and I made up all these lies. Then finally my father had to answer my question for me which was very very emberssing for me. Then after he had to answer my question for me he pushed me out of madeline,s room and made me go face first into the wall. And at that moment I ended up with a lump on the head. I was really ashamed of myself then. From then on I was no longer allowed into my sister,s bedroom anymore. My father was really mad at me for what I had done. He was not pleased with me at all either. Then after that had happened he one time asked me to go into her room at one time and at that point I said to him that I was no longer allowed into her room then after I said that to him he said that I could go into her room and I said to him that I was not allowed into her bedroom anymore then he started to lose his pacients with me at that very moment . I was in very deep trouble at that moment . ${ }^{29}$

What is represented here is the voice of the other, a relatively rare phenomenon in the genre of disability literature, where the dominant mode is the parent speaking for the disabled child. ${ }^{30}$ The passage reveals a great deal and, in effect, demonstrates that Adam is not a "catastrophic" adoptee, but a young man with feelings and an intuitive sense of family dynamics. A range of emotions is expressed, including guilt, embarrassment, shame, and perhaps defiance, and, as in Twain's Huck Finn, it is clear that naïve narration (both fictional and autobiographical) can be rich in implication. The parental anger, for one thing, seems extreme, perhaps expressing Dorris's fears that Adam could have incestuous feelings for Madeline (the younger adopted daughter). The scene is archetypal: fear of the uncontrolled sexuality of the Native other; Prospero chiding Caliban. It is a very clear example of "speaking for the other," in which Dorris as father poses "over and over and over" again rhetorical questions that he ends up answering himself, a mode of discourse which represents the book as a whole. Adam, for his part, arguably offers resistant counter discourse, turning the very words of power against themselves ("Go into her room? No, I won't, you told me not to"), like Caliban using the master's language to swear at him. So Adam is given a voice at the end, but as the dominant discourse is Dorris's, Adam's postscript is framed within that discourse. The final word of The Broken Cord is an appeal for donations to a foundation furthering research on fetal alcohol syndrome. As Couser has argued, in The Broken Cord Adam moves from being an actual individual to being a case study of "preventable disability.",31

The Broken Cord could be read as an account of intertribal adoption in that Dorris was part Modoc and Adam was pureblood Lakota Sioux. However, Dorris's tribal links before adopting Adam were at best tenuous, and as a Yale-trained anthropologist and later director of the Native American Studies Department at Dartmouth College, in Couser's words: "Dorris was a highly assimilated mixed-blood, whose attenuated relation to his Native American heritage was mediated by his profession."32 Elizabeth Lynn-Cook, herself, like "Adam," a Lakota Sioux, strongly critiques Dorris for his blindness to the possibilities of within-tribe adoption and within-tribe healing by traditional methods, arguing that "the adoption of Sioux children by those outside of the specific tribal perspective breaks one of the first rules 
of tribal sovereignty." 33 It was, she reminds us, out-of-tribe adoption that prompted the enactment of the 1978 Indian Child Welfare Act, an Act with the tenets that Indian relatives "be responsible to one another within the tribal context" rebuttal of out-of-tribe adoption and of Dorris's book, Lynn-Cook writes: "Indian communities deplore the taking of their children." 35 Statistics would seem to support the claim that the extent of out-of-tribe adoption was excessive, and that adoption, like the residential school system, had become a form of forced cultural assimilation.

\section{Representations of FAS and Disability in Recent Native North American Writing}

Whereas we have in Michael Dorris's The Broken Cord a biography of a Native child with FAS being adopted out of the birth tribe, representations of disabled individuals in works by Tomson Highway and Louise Erdrich show impaired individuals either being raised and nurtured within the tribal community, or taken care of by the Native birth mother. The underlying implication is that the tribe can take care of their own.

In Highway's first two major plays, we have two portraits of disability: Zhaboonigan Peterson, a young woman with intellectual disability in The Rez Sisters, and Dickie Bird Halked, a FAS victim in Dry Lips. Zhaboonigan's parents died in a car crash, and she has been adopted within the tribal community by the childless Veronique St Pierre. Dickie Bird has been brought up by his mother but the identity of his biological father has been kept secret.

Whereas we have seen the dangers of speaking for the disabled other in The Broken Cord, Highway's plays attempt to present the unmediated voice of disabled individuals. Thus, in The Rez Sisters, Zhaboonigan alludes to her rape by two white boys and the origin of her name:

It was a. Screwdriver. They put the screwdriver inside me $\div$. Here. Remember. Ever lots of blood. The two white boys. Left me in the bush. Alone. It was cold. And then. Remember. Zhaboonigan. Everybody calls me Zhaboonigan. Why? It means needle. Zhaboonigan. Going-through-thing. Needle Peterson. Goingthrough-thing Peterson. That's me. ${ }^{36}$

Complex notions are expressed here through highly restricted diction. Names are equated with identity (particularly true in tribal naming), and here Zhaboonigan's very name continuously returns her to the site of trauma ("Remember [...] Remember"). In Dry Lips, Dickie Bird's name also references the site of trauma, in his case the Dickie Bird Tavern where he was born. Rather than seeing the handicapped adoptee as "lacking imagination" or as source of regret, as in Dorris's The Broken Cord, Zhaboonigan is represented as having special powers of spiritual insight. It is she (along with a woman dying of cancer) who alone among the rez women can sense the presence of the Anishinaabe trickster-figure Nanapush, who represents in Highway's work the continuing spirit of tribal survival.

Highway's positive portrayal of an adoptee with both an intellectual disability and a victim of violence takes place within a non-idealized reservation environment, which shows both bickering and infighting among the women, but ultimately a solid and supportive community. In Highway's Dry Lips, the "flip side" play to The Rez Sisters, the rez women form a women's hockey team and initially deny Veronique S Pierre the right to join by only valuing the essentialist notion of biological motherhood ("the other women wouldn't let her [Veronique] in on account she had no babies.") Veronique's spirited defense,

"Zhaboonigan Peterson may be just my adopted daughter and she may be retarded as a doormat but she's still my baby," 37 actually falls on receptive ears among the other women, and she is allowed to join the team. It is significant, I find, that Veronique is not represented as an all-embracing earth mother figure, 
but is, in fact, generally disliked for her interfering ways. She is neither the idealized nor the demonized adoptive mother, but her role in facilitating tribal continuity is clear when Marie-Adele's death from cancer leaves "14 little orphans" of tribal adoption, and adoption as a symbol of tribal survival, largely unmentioned by other critics of Highway's work, is, in fact, central.

Highway's other portrait of disability is 17-year-old Dickie Bird Halked who, despite his FAS-induced extreme violence is neither marginalized nor rejected by the rez community. Dickie Bird's mother, Black Lady Halked, is an alcoholic, who gives birth to her son in an alcoholic haze in the local tavern. His biological father, Big Joey, is a misogynist who avoids vital assistance to Black Lady when she is about to give birth. Dickie Bird is represented as a deeply disturbed individual, rendered virtually speechless both by his FAS condition and by his desperate search for meaning and identity. Primarily, his search is for the absent biological father; indeed, one of Highway's major points in Dry Lips is the need for both male and female responsibility, a theme conveyed through the playing of Kitty Wells's “It Wasn't God Who Made Honky Tonk Angels" on the jukebox as Dickie is born. ${ }^{39}$

Dickie's inarticulacy is a physical manifestation of psychic and spiritual confusion, culminating in his rape of a young Native woman, Patsy Pegahmagahbow, with a crucifix. In the play, Patsy is clearly represented as both a female character and as an incarnation of the Ojibwe trickster Nanapush. In this scene, a violent image of the psychic effect of colonizing Christianity, Highway overloads the FAS victim with symbolic significance. David Mitchell and Sharon Snyder have called this "narrative prosthesis," that is, the use of sick and disabled characters as "opportunistic metaphorical devices." to emphasize is that even this deranged and violent individual is not represented as being outside the tribal community. Indeed, the arc of the narrative shows him to be, if anything, reintegrated into the tribe, and he even acts as an integrator himself. Thus, one of the key scenes in the play is when Big Joey acknowledges that he is in fact Dickie Bird's natural father. Nor is there any tribal reproof of Dickie Bird on account of the rape. As one of the men says to him: "Don't you worry a wart about that court appearance, Dickie Bird Halked. I'll be right there beside you tellin' that ole judge a thing or two about that goddam jukebox." ${ }^{41}$ In other words, Dickie Bird is not made responsible for his birth beside the jukebox. His extreme actions and disturbed behavior are understood as the result of FAS. Or, in symbolic terms, Dickie is represented as the product of the twin colonial "gifts" of alcohol and Western religion.

Another representation of a child with FAS is found in Louise Erdrich's Four Souls, and again the same point can be made: the Indigenous child with disability is not "adopted out" or marginalized, and can even play a significant role within the fabric of the tribal community. Four Souls begins with the protagonist, Fleur Pillager, leaving her tribal home intent on murdering the lumber baron, John James Mauser, who destroyed the trees on her land. To fully exact revenge, she marries Mauser after he promises to bequeath her his estate. Finding herself pregnant, and after a near miscarriage, she is prescribed whiskey by Mauser's well-meaning sister-in-law, Polly Elizabeth, a treatment that the doctor supports. The resulting child, John James Mauser II, is willful, mute, addicted to sugar, and prone to sitting on the floor, his fist in his mouth, rocking endlessly backward and forward, staring at nothing. ${ }^{42}$ In Erdrich's portrait of a child with FAS, the link between alcohol and mental disability is not made by the characters in the novel themselves, but this is historically accurate in the sense that the link between maternal alcohol intake and FAS was only established relatively late in the twentieth century and the novel is set in the 1920s and early 1930s. Medical ignorance is, in fact, part of the tragicomic theme of the novel, for John James's condition is diagnosed by the doctor as "a tragical mistake, the effect of an aberrant spermatozoa deformed by the long practice of Karezza [the withholding of ejaculation]."

Louise Erdrich's own perspective on FAS is worth pondering here. As an adoptive parent with Michael Dorris of a child with FAS, and someone who, in the preface of The Broken Cord, advocated incarceration 
for alcoholic pregnant women to avoid potential FAS damage to their unborn children, it is difficult not to factor the biographical into the literary text. The events of Fleur's pregnancy and birthing are focalized through the medically naïve narration of Polly Elizabeth, and there is no editorializing about the motherto-be's responsibilities to the unborn child. Thus, in Four Souls, no direct blame is attached to Fleur as the alcoholized mother, for she is unaware that alcohol could affect her unborn child and is, in effect, taking alcohol under doctor's orders. The scenes where the young child is given small quantities of alcohol as the only way to stem his cries are also represented without reproof by Polly Elizabeth as "medicinal drinking." 44 What is stressed, however, is the steadfast bond between mother and child, "She [Fleur] had a heart [...] a heart that stood both fast and passionate when it came to defending those she loved.",45 There is no thought of adopting out the child, despite his disabilities, and indeed, after Fleur's and Mauser's divorce, the narrative sees mother and child becoming increasingly integrated into the tribal community. The theme of the homecoming return of the Native in order to heal appears once again, and this change in focus is foregrounded by the shift in narration, for the last section of the novel is narrated in alternate chapters by the tribal patriarch Nanapush and his common-law wife, Margaret.

Towards the end of Four Souls John James's special qualities, rather than his disability, are foregrounded, for it is his exceptional card skills that enable his mother to "come home." Just as Zhaboonigan in Highway's Dry Lips is shown as almost uniquely in touch with the Cree/Ojibwe spirit world, so, too, John James in Four Souls reveals exceptional gifts and, in effect, takes on the role of the Anishinaabe trickster culture hero. In Ojibwe legend, the trickster Nanapush saves his people by outwitting the deadly gambler. In Four Souls, John James's idiot savant skills in poker win back Fleur's land from the hands of the white former Indian agent Jewett Tatro. John James's disability throughout the novel has been categorized by all as "vacancy," and now the boy's "idiot's trance" 46 convinces Tatro that the game is his, although he soon finds out that "vacancy" can be an enormous advantage in poker, making him "unreadable" as an opponent. Disability scholars, like Michael Bérubé, have been critical of the potential romanticization of the "linkage of exceptionality with disability." 47 However, as LavonaLavonna Lovern has recently pointed out, in the Native American worldview, exceptionality, even disability, can be of social and personal value within the community, and this notion is something that might be more widely accepted within dominant cultures. ${ }^{48}$

The final full chapter of Four Souls, narrated by Nanapush's long-term companion, Margaret Kashpaw, is titled "The Healing." Healing is associated with tribal homecoming and tribal values, and Margaret provides an Ojibwe perspective on John James's condition by assuming that his unusualness is the result of Fleur not following tribal practices concerning naming: "You haven't named your own son [...]. He's strange in the head because the spirits don't know him!" "49 John James's "strangeness" can be seen as a blank canvas on which different perspectives are writ large. The quackery of the medical profession is represented by the doctor's diagnosis that the boy's vacancy is the result of the unnatural sexual practice of KabeezaKarezza, while Mauser's guilt at his business rapacity and ill-treatment of Native peoples means that he sees his son's condition as a punishment from God. The medically informed reader, of course, is most likely to ascribe the child's behavior to FAS. However, because of the shift in narrative perspective, the reader at the end of the novel is likely to be swayed by Margaret's Ojibwe worldview. Fleur is disrobed of her stylish Western clothing, bathed and rerobed in a medicine dress, which she must wear as she undergoes an eight-day purgation alone without food on a rock at the side of the lake. Fleur's obsession with revenge can, then, be purged, and she can more readily open herself to love and her children's needs: "your first child [Lulu] does not love you and your second child [John James] doesn't know how. How can they love a woman who has wasted her souls?"50 Notably, the closing focus is not on a child's disability (as in Dorris's The Broken Cord), but on the kind of openness that is required of a parent to fulfill a child's needs, perhaps particularly a child with special needs. The novel closes with Fleur earning the right to be given her mother's name, Four Souls, and the suggestion that she (and her son) will become more fully integrated into the tribal community. 
As with all Erdrich's novels, the reader is permitted to see how her characters evolve in later life as, much like Faulkner, she develops her creations in other novels. John James is represented as an adult in Last Report on the Miracles at Little No Horse (2002). He has been given the tribal name of Awun (The Mist), which reflects both his size and his strange vacancy. His behavior, though unusual, is not found unacceptable by the tribal community. His abduction of the nun Mary Kashpaw ends in a marriage of mutual affection and they have a child, the wildly irresponsible trickster-like Jack Mauser who appears in Tales of Burning Love (1996). In Erdrich's fiction, therefore, it is possible to have FAS and a full life, the unpredictability and strangeness of such individuals (and their offspring) being only a matter of degree within the larger chaos and unpredictability of everyday life either on or off the reservation.

In my study of different representations of FAS and adoption in three Native North American writers, Michael Dorris's autobiographical work can be viewed within the paradigm of the "disastrous adoption," centering on the author's realization that "nature" will triumph over "nurture." effort is spent, the unwieldy clay of a child with FAS can never be transformed into a fully fulfilled and creative self. In the emotive tones of Dorris's closing words, his adopted son will "forever travel through a moonless night with only the roar of wind for company." figures with disabilities who play an integral part within the tribal community and may even offer special gifts. There is no implication that the tribal community cannot take care of their own. Thus, I would argue, they represent a form of resistance to the notion of "adopting out," and imply an alternative stance to disability and to transracial and transnational adoption.

\section{Notes}

1. Marianne Novy (ed.), Imagining Adoption: Essays on Literature and Culture (Ann Arbor: The University of Michigan Press, 2004), 1.

2. Susan Fournier and Ernie Crey, Stolen From Our Embrace: The Abduction of First Nations Children and the Restoration of Aboriginal Communities (Vancouver/Toronto: Douglas and McIntyre, 1998), 83.

3. Fournier and Crey, Stolen From Our Embrace, 88.

4. Legislative History for the Indian Child Welfare Act of 1978 (ICWA), accessed February 16, 2017, http://caicw.org/family-advocacy/legislative-history/\#.WKU1U3rl-XA .

5. Truth and Reconciliation Commission of Canada, TRC Final Report, June 2, 2015, 1. Accessed November 1, 2016, http://www.trc.ca/websites/trcinstitution/index.php?p=26 .

6. See Mark Shackleton, "The Return of the Native American: The Theme of Homecoming in Contemporary Native American Fiction," The Atlantic Literary Review 3: 2 (2002): 155-164.

7. See Pirjo Ahokas's chapter in this volume: "Indigenous Identity, Forced Transracial Removal, and Intergenerational Trauma in Linda Hogan's Solar Storms and Sherman Alexie's Indian Killer."

8. Siobhan Senier, "Rehabilitation Reservations. Native Narrations of Disability and Community," Disability Studies Quarterly 32: 4 (2012), accessed February 15, 2017, http://dsq-sds.org/article /view/1641/3193 .

9. John McLeod, Life Lines: Writing Transcultural Adoption (London: Bloomsbury, 2015), 4. 
McLeod writes: "I fashion the term 'adoptive being' to capture the distinct and transfigurative rendition of transcultural adoption possibilities as it emerges across a range of creative texts."

10. A positive representation by a non-Native writer of the adoption of a Cherokee child by a white woman is found in Barbara Kingsolver's The Bean Trees (1988) and Pigs in Heaven (1993). For an analysis of the problematic nature of these novels, see Kristina Fagan "Adoption as National Fantasy in Barbara Kingsolver's Pigs in Heaven and Margaret Laurence's The Diviners," and Chap. 4 , "Bearings," in John McLeod's Life Lines.

11. Novy (ed.), Imagining Adoption, 1.

12. Michael Dorris, The Broken Cord (New York: Harper and Row, 1989), 197.

13. G. Thomas Couser, "Adoption, Disability, and Surrogacy: The Ethics of Parental Life Writing in The Broken Cord," Vulnerable Subjects: Ethics and Life Writing, G. Thomas Couser (Ithaca and London: Cornell University Press, 2004), 57.

14. Dorris, The Broken Cord, 201.

15. Dorris, The Broken Cord, 245.

16. Dorris, The Broken Cord, 138.

17. Dorris, The Broken Cord, 264.

18. Dorris, The Broken Cord, 262.

19. Dorris, The Broken Cord, 230-231.

20. Dorris, The Broken Cord, 76.

21. Elizabeth Cook-Lynn, "The Broken Cord," in Why I Can't Read Wallace Stegner, and Other Essays: A Tribal Voice (Madison: University of Wisconsin Press, 1996), 11.

22. Margit Stange, "The Broken Self: Fetal Alcohol Syndrome," in Body Politics, Disease, Desire, and the Family, ed. Michel Ryan and Avery Gordon (Boulder: Westview, 1994), 129.

23. Dorris, The Broken Cord, 264.

24. Dorris, The Broken Cord, 264.

25. Gerald Vizenor, "Postindian Warriors," in Manifest Manners: Postindian Warriors of Survivance (Hanover, NH: Wesleyan University Press, 1994), 31.

26. See John McLeod's chapter in this volume: "Cruel Chronologies: Ireland, America and Transatlantic Adoption in The Lost Child of Philomena Lee and Philomena."

27. Couser writes: “in the fact that Adam's narrative is preceded and introduced by his father's, the book as a whole is akin to what Arnold Krupat calls 'the Indian autobiography,' which is 'jointly produced by some white who translates, transcribes, compiles, edits, interprets, polishes, and 
ultimately determines the form of the text in writing, and by an Indian who is its subject and whose life becomes the content of the "'autobiography."." Couser, "Adoption, Disability, and Surrogacy," 64.

28. Dorris, The Broken Cord, 264.

29. Dorris, The Broken Cord, 276275-76.

30. Couser, "Adoption, Disability, and Surrogacy," 63.

31. Couser, "Adoption, Disability, and Surrogacy," 73.

32. Couser, "Adoption, Disability, and Surrogacy," 62.

33. Cook-Lynn, “The Broken Cord,” 15.

34. Cook-Lynn, "The Broken Cord," 15.

35. Cook-Lynn, "The Broken Cord," 15-16.

36. Tomson Highway, The Rez Sisters (Calgary: Fifth House, 1988), 47-48.

37. Tomson Highway, Dry Lips Oughta Move to Kapuskasing (Calgary: Fifth House, 1989), 29-30.

38. Highway, The Rez Sisters, 111.

39. Kitty Wells's "It Wasn't God Who Made Honky Tonk Angels" is an answer song to Hank Thompson's "The Wild Side of Life." Thompson's song puts the blame for failed marriages on women's infidelity; Wells's reply rejects double standards, requiring men to acknowledge their own responsibilities: "Too many times married men/Think they're still single/That has caused many a good girl to go wrong."

40. Mitchell, David T. and Sharon L. Snyder, Narrative Prosthesis: Disability and the Dependencies of Discourse (Ann Arbor: University of Michigan Press, 2000), 47.

41. Highway, Dry Lips, 123.

42. Louise Erdrich, Four Souls (London: Harper Perennial, 2006), 120.

43. Erdrich, Four Souls, 121.

44. Erdrich, Four Souls, 68.

45. Erdrich, Four Souls, 122.

46. Erdrich, Four Souls, 197.

47. Michael Bérubé, "Disability and Narrative," PMLA: Publications of the Modern Language Association of America 120: 2 (2005): 569. 
48. Senier, "Rehabilitation Reservations."Lavonna Lovern. "Native American Worldview and the Discourse of Disability." Essays in Philosophy 9: 1, Article 14 (2008). Accessed February 13, 2017. http://commons.pacificu.edu/eip/vol9/iss1/14/ .

49. Erdrich, Four Souls, 209200.

50. Erdrich, Four Souls, 206.

51. Dorris, The Broken Cord, 231.

52. Dorris, The Broken Cord, 264.

\section{Bibliography}

Alexie, Sherman. Indian Killer. London: Vintage, 1998.

Bérubé, Michael. "Disability and Narrative." PMLA: Publications of the Modern Language Association of America 120: 2 (2005): 568-76.

Cook-Lynn, Elizabeth. “The Broken Cord.” In Why I Can't Read Wallace Stegner, and Other Essays: A Tribal Voice, 11-16. Madison: University of Wisconsin Press, 1996.

Couser, G. Thomas. "Adoption, Disability, and Surrogacy: The Ethics of Parental Life Writing in The Broken Cord." In G. Thomas Couser, Vulnerable Subjects: Ethics and Life Writing, 56-73. Ithaca and London: Cornell University Press, 2004.

Dorris, Michael. The Broken Cord. New York: Harper \& Row, 1989.

Erdrich, Louise. Tales of Burning Love. London: Flamingo, 1997.

Erdrich, Louise. Last Report on the Miracles at Little No Horse. London: Flamingo, 2002.

Erdrich, Louise. Four Souls. London: Harper Perennial, 2006.

Fagan, Kristina. "Adoption as National Fantasy in Barbara Kingsolver's Pigs in Heaven and Margaret Laurence's The Diviners." In Imagining Adoption: Essays on Literature and Culture, edited by Marianne Novy, 251-66. Ann Arbor: The University of Michigan Press, 2004.

Fournier, Susan, and Ernie Crey. Stolen From Our Embrace: The Abduction of First Nations Children and the Restoration of Aboriginal Communities. Vancouver/Toronto: Douglas and McIntyre, 1998.

Highway, Tomson. Dry Lips Oughta Move to Kapuskasing. Calgary: Fifth House, 1989.

Highway, Tomson. The Rez Sisters. Calgary: Fifth House, 1988.

Highway, Tomson. Kiss of the Fur Queen. Toronto: Doubleday, 1998.

Krupat, Arnold. For Those Who Come After: A Study of Native American Autobiography. Berkeley: University of California Press, 1985. 
Legislative History for the Indian Child Welfare Act of 1978 (ICWA). Accessed February 16, 2017. http://caicw.org/family-advocacy/legislative-history/\#.WKU1U3rl-XA .

Lovern, Lavonna. "Native American Worldview and the Discourse of Disability." Essays in Philosophy 9: 1, Article 14 (2008). Accessed February 13, 2017. http://commons.pacificu.edu/eip/vol9/iss1/14/ .

McLeod, John. Life Lines: Writing Transcultural Adoption. London: Bloomsbury, 2015.

Mitchell, David T., and Sharon L. Snyder. Narrative Prosthesis: Disability and the Dependencies of Discourse. Ann Arbor: University of Michigan Press, 2000.

Mosionier, Beatrice Culleton. In Search of April Raintree. Winnipeg: Portage \& Main Press, 1999.

Neihardt, John G. Black Elk Speaks: Being the Life Story of a Holy Man of the Oglala Sioux. Lincoln and London: University of Nebraska Press, 1988.

Novy, Marianne (ed.). Imagining Adoption: Essays on Literature and Culture. Ann Arbor: The University of Michigan Press, 2004.

Senier, Siobhan. "Rehabilitation Reservations. Native Narrations of Disability and Community." Disability Studies Quarterly 32: 4 (2012). Accessed February 15, 2017. http://dsq-sds.org/article /view/1641/3193.

Shackleton, Mark. "The Return of the Native American: The Theme of Homecoming in Contemporary Native American Fiction." The Atlantic Literary Review 3: 2 (2002): 155-64.

Silko, Leslie Marmon. Ceremony. New York: Penguin, 2006.

Fruth and Reconciliation Commission of Canada, TRC Final Repert, June 2, 2015. Accessed November 1, 2016. http://www.trc.ca/websites/trcinstitution/index.php?p=26.

Stange, Margit. “The Broken Self: Fetal Alcohol Syndrome.” In Body Politics, Disease, Desire, and the Family, edited by Michel Ryan and Avery Gordon, 126-36. Boulder: Westview, 1994.

Vizenor, Gerald. “Postindian Warriors.” In Manifest Manners: Postindian Warriors of Survivance, 1-44. Hanover, NH: Wesleyan University Press, 1994.

Vizenor, Gerald. Father Meme. Albuquerque: University of New Mexico Press, 2008. 